\title{
Spectrophotometric determination of hesperidin in supplements and orange juices
}

\author{
Leposava Pavun ${ }^{1}$, Snežana \\ Uskoković-Marković2,*
}

${ }^{1}$ Department of Physical Chemistry and Instrumental Methods, Faculty of Pharmacy, University of Belgrade, Vojvode Stepe 450, 11221 Belgrade, Serbia

${ }^{2}$ Department of Analytical Chemistry, Faculty of Pharmacy, University of Belgrade, Vojvode Stepe 450, 11221 Belgrade, Serbia

\author{
${ }^{*}$ Corresponding author: \\ Snežana Uskoković-Marković \\ Department of Analytical Chemistry \\ Faculty of Pharmacy \\ University of Belgrade \\ Vojvode Stepe 450, 11221 Belgrade, Serbia \\ Phone: +381113951261 \\ Fax: +381113972 840 \\ E-mail address: \\ snezaum@pharmacy.bg.ac.rs
}

\begin{abstract}
Hesperidin is the flavonoid heteroside most found in citrus species, such as grapefruit, lemon and orange. It is applied in the treatment of numerous cardiovascular diseases, with many products containing hesperidin in combination with other flavonoid heterosides or vitamin C. The aim of this study was to develop and validate a simple, rapid and sensitive and lowcost method for determination of hesperidin in tablets and orange juices. The developed spectrophotometric method is based on the formation of the $\mathrm{Zn}$ (II)-hesperidin complex in $70 \mathrm{v} / \mathrm{v} \%$ methanol at $\mathrm{pH} 3.12$, with max of absorption at $\lambda \max =283 \mathrm{~nm}$. The method of variation of equimolar solutions confirmed the stoichiometry of the complex as hesperidin: zinc= 2:1. The stability constant of the complex was obtained by the Bjerrum method and it is $\log \beta 2=17.01$ at $\mathrm{pH}$ 3.12. Linearity range for the developed method was defined as $0.61-7.32 \mathrm{\mu g} / \mathrm{mL}$, (confirmed by coefficient of determination, $r 2=0.9882)$, while limits of detection and quantification were calculated as $L O D=0.15 \mu \mathrm{g} / \mathrm{mL}$ and $L O Q=0.45 \mu \mathrm{g} / \mathrm{mL}$. Fairly high precision of the method is indicated by low values of CV, varying in the range $0.26-1.23 \%$. The proposed method fulfills all aimed requirements, and it was successfully applied for determination of hesperidin in tablets with recovery value 92.2 $\%$ and commercially available orange juices.
\end{abstract}

Key words: hesperidin, orange juice, spectrophotometry, zinc complex.

\section{INTRODUCTION}

Flavonoids as the biggest group of plant polyphenols are widespread, but mostly can be found in angiosperms. Actually, they are pigments responsible for the flowers, fruits and leaves colors, but they also take parts in numerous metabolic and physiologic processes in plants.

Availability of citrus fruits all around the world nowadays, during the whole year, leads to numerous studies focused on the effects of hesperidin (Hesp), a flavonoid that consists of aglycone hesperitin and sugar rutinoside (Figure 1).

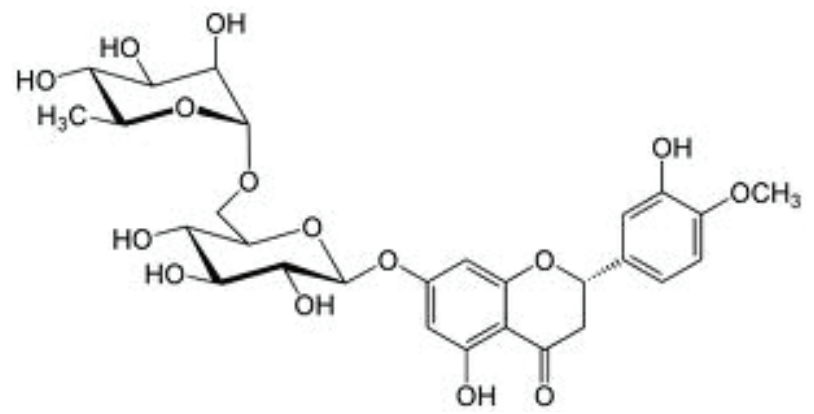

Hesperidin is flavanone mainly stored in the inner peel of citrus fruits, called albedo. Hesperidin can be used alone or in combination with other bioflavonoids and/or vitamin $\mathrm{C}$ as dietary supplements.

Positive effects of hesperidin are mainly attributed to its strong antioxidant activity, increasing its ability to scavenge free radicals [1]. Some of the most often reported positive effects of hesperidin are anti-inflammatory, antiallergenic, antiviral and anticarcinogenic effect [2]. Hesperidin contributes to strength of the blood vessels walls, leads to the bruise preventing and some conditions related to certain vascular disorders [3]. Further, even promising effects of orange juice daily consumption have been reported as the results of performed studies, such as lowering of diastolic blood pressure [4]. Further, significant radioprotective effect of hesperidin has been reported [5].

As a very important fact in hesperidin usage, no signs of toxicity have been reported with the normal intake of hesperidin or related compounds. Further, both hesperidin and its aglycone hesperetin have been observed to possess a wide range of pharmacological properties.

Figure 1. The molecular structure of hesperidin 
Hesperidin possesses the strong ability to form complexes with transition metal ions, helping the plant defense mechanism against the pathogens and planteaters. The same ability of metal ions complexation is used as the quality test for the presence of flavonoids in extracts and biological specimens.

Hesperidin can be determined alone and/or with other flavonoids by many methods, such as HPLC $[6,7]$, adsorptive-stripping voltammetry [8], spectrophotometry $[9,10]$, and pulse perturbation of the oscillatory reaction system [11]. The very sensitive method for hesperidin determination in plasma has been reported to be liquid chromatography tandem mass spectrometry (LC-MS/MS) [12].

Considerable numbers of the reported methods are based on the analysis of flavonoid-metal complexes with aim to follow the quality control of dietary supplements and food products.

Previously, we have developed the methods for the determination of hesperidin in human plasma and pharmaceutical forms based on the fluorescence properties of the aluminium-hesperidin complex in the presence of zwiterionic surfactant sulfobetaine - SB 12 [13], and without presence of surfactant [14]. The methods have great sensitivity but a spectrofluorimeter is still a too expensive instrument for regular daily control of the products.

In this work we have proposed a spectrophotometric method based on the absorption of the zinc(II) hesperidin complex for the determination of hesperidin. We have tested and chosen the optimal conditions for the formation of zinc(II) - hesperidin complex with aim to apply the developed method for the quantification of hesperidin in tablets and several samples of orange juices.

\section{MATERIAL AND METHODS}

\section{Reagents and Materials}

Hesperidin (Fluka AG), methanol, $\mathrm{NaOH}, \mathrm{CH}_{3} \mathrm{COOH}$, $\mathrm{CH}_{3} \mathrm{COONa}$, zinc-chloride, (Merck), all p.a. grade, were used. The stock solution of zinc-chloride $\left(1.0 \times 10^{-4}\right.$ $\mathrm{mol} / \mathrm{L}$ ) was prepared by dissolving $\mathrm{ZnCl}_{2}$ in doubly distilled water. The stock solution of hesperidin $\left(1.0 \times 10^{-4}\right.$ $\mathrm{mol} / \mathrm{L})$ was prepared by dissolving hesperidin in methanol (70 \% v/v) and was stored in a refrigerator.

Working solutions of the zinc(II)-hesperidin complex was prepared by dilution of the stock solutions of zinc(II) $\left(2.5 \times 10^{-5} \mathrm{~mol} / \mathrm{L} \mathrm{ZnCl}_{2}\right.$ and hesperidin $\left(5.0 \times 10^{-7}\right.$ to $\left.1.0 \times 10^{-5} \mathrm{~mol} / \mathrm{L}\right)$.

Acetate buffers (in 70 wt\% methanol and $\mathrm{pH} 3.12$ ), previously prepared according to Perrin [15], were used for all spectrophotometric measurements.

\section{Instruments}

Spectrophotometric measurements were performed on a Beckman DU-650 spectrophotometer, using $1 \mathrm{~cm}$ of quartz cells.
Measurements of $\mathrm{pH}$ were carried out using a Mettler Toledo mp $120 \mathrm{pH}$ meter, equipped with a combination electrode.

\section{Sample preparation}

Procedure for analysis of hesperidin in pharmaceutical preparations

Chosen tablets Helopyrin (Rosch \& Handel, Vienna, Austria) were prepared for analysis according the following procedure. Ten tablets were weighed and powdered using pestle and mortar. A portion of the powder, equivalent to weight of one tablet, was dissolved in $100 \mathrm{~mL} 70 \mathrm{v} / \mathrm{v} \%$ of methanol and kept in an ultrasonic bath at $25^{\circ} \mathrm{C}$ for $30 \mathrm{~min}$, after which the solution was filtered through Millipore membrane filter.

Appropriate volumes of each filtrate and a $3.0 \mathrm{~mL}$ portion of $1.0 \times 10^{-4} \mathrm{~mol} / \mathrm{L} \mathrm{ZnCl}_{2}$ were mixed in a volumetric flask of $10 \mathrm{~mL}$ and diluted to the mark with 70 $\mathrm{v} / \mathrm{v} \%$ methanol. The expected concentration of hesperidin in prepared solutions was approximately $5.0 \times$ $10^{-6} \mathrm{~mol} / \mathrm{L}$. Values of $\mathrm{pH}$ of these solutions were adjusted to 3.12. The absorbance of prepared solutions was measured at $\lambda_{\max }=283 \mathrm{~nm}$ against $70 \mathrm{v} / \mathrm{v} \%$ methanol at $\mathrm{pH} 3.12$ as blank.

All measurements were performed in triplicate. Origin 7 software was used for all necessary calculations and to obtain appropriate analytical parameters.

\section{Procedure for analysis of hesperidin in orange juices}

To the aliquot of $0.25 \mathrm{~mL}$ of tested orange juice, add $2.5 \mathrm{~mL} \mathrm{ZnCl}{ }_{2}$ of concentration $2.5 \times 10^{-5} \mathrm{~mol} / \mathrm{L}$ and 7.25 $\mathrm{mL}$ of acetate buffer $\mathrm{pH} 3.12$ in methanol and centrifuge at $900 \mathrm{rpm}$ for $5 \mathrm{~min}$. Measured absorbance of transparent supernatant at $\lambda_{\max }=283 \mathrm{~nm}$ with $70 \mathrm{v} / \mathrm{v} \%$ methanol at pH 3.12 as blank was used with previously obtained calibration curve to calculate the hesperidin content in tested samples.

\section{RESULTS AND DISCUSSION}

\section{Complex formation between hesperidin and zinc(II)-ion}

Hesperidin is poorly soluble in water, but it dissolves in methanol, where the water and methanol ratio strongly affects the solubility of hesperidine. It was found that the most favorable ratio of methanol to water is 70:30, since that is the optimum condition for the formation of the $\mathrm{Zn}^{2+}$-hesperidin complex.

Apsorption spectra of hesperidin, $\mathrm{ZnCl}_{2}$, and $\mathrm{Zn}$-hesperidin complex solutions were recorded in the range $250 \mathrm{~nm}-400 \mathrm{~nm}$ against $70 \mathrm{v} / \mathrm{v} \%$ methanol as blank. The complex is stable in a wide range of $\mathrm{pH}$ values, from $\mathrm{pH} 1$ to $\mathrm{pH}$ 7. It is confirmed that complex $\mathrm{Zn}^{2+}-$ Hesp shows maximum of absopbance at $\lambda_{\max }=$ $283 \mathrm{~nm}$, at pH 3.12, while the solution of $\mathrm{ZnCl}_{2}$ does 
not exhibit considerably significant absorbance in the same range, $250-400 \mathrm{~nm}$.

The ratio of $\mathrm{Zn}^{2+}$ and hesperidin in their complex were determined by the method of variations of equimolar solutions [16], prepared in acetate buffer $\mathrm{pH} 3.12$ in $70 \%$ methanol; as a result, the complex was defined as $\mathrm{ZnHesp}_{2}$. The composition of the zinc - hesperidin complex was also followed by the mole ratio method [17], confirming the zinc-hesperidin ratio 1:2 for the complex formed at $\mathrm{pH} 3.12$.

The dependence of absorbance intensity on $\mathrm{pH}$ was tested in the acetate buffers (in $70 \mathrm{v} / \mathrm{v} \%$ methanol) of different $\mathrm{pH}$ values, prepared according to Perrin [15]. Figure 2 represents the absorbance intensity as function of solution $\mathrm{pH}$, where the strong $\mathrm{pH}$ dependence can be noticed.

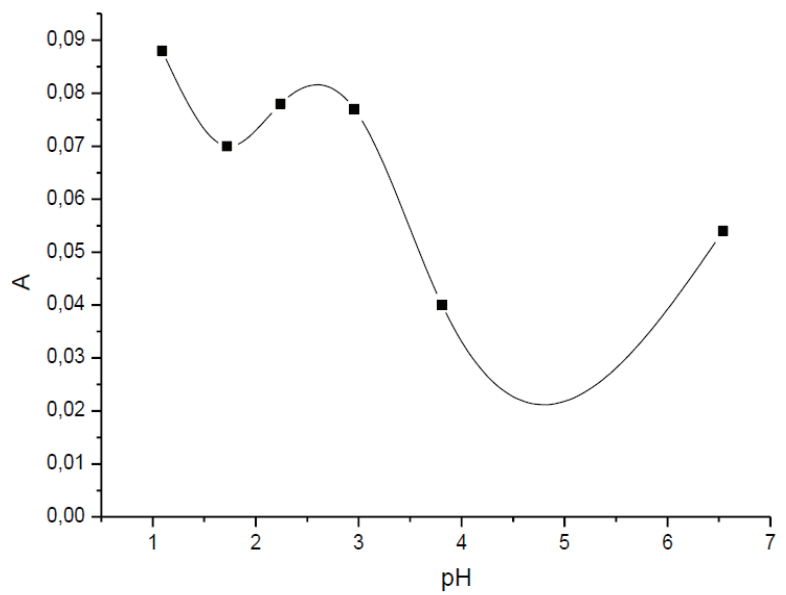

Figure 2. Dependence intensity of absorbance on the $\mathrm{pH}$

\section{Spectrophotometric determination of hesperidin- method development}

For the spectrophotometric determination of hesperidin based on absorbance depending on the concentration of formed $\mathrm{Zn}^{2+}$-hesperidin complex, the calibration curve method was applied. Eight solutions of hesperidin were prepared, with hesperdin concentrations increasing from $1.0 \times 10^{-6} \mathrm{~mol} / \mathrm{L}$ to $1.2 \times 10^{-5}$ $\mathrm{mol} / \mathrm{L}$, while $\mathrm{Zn}^{2+}$ ion was in excess, $\mathrm{c}=2.5 \times 10^{-5} \mathrm{~mol} / \mathrm{L}$. All used solutions were prepared in acetate buffer, $\mathrm{pH}$ 3.12. Solutions were prepared $0.5 \mathrm{~h}$ prior to spectra recording at $\lambda=283 \mathrm{~nm}$ against $70 \% \mathrm{v} / \mathrm{v}$ methanol as blank.

\section{Linearity}

The high value of the stability constant of the zinc(II) - hesperidin complex guarantees the quantitative determination of hesperidin based on the absorbance characteristics of the complex. The calibration curve method was used, requiring solutions containing constant concentration of $\mathrm{ZnCl}_{2}$ and different concentrations of hesperidin in acetate buffer pH 3.12 (70 v/v \% methanol as solvent) and acetate buffer $\mathrm{pH} 3.12$ as blank. Linear dependence of the absorbance of the complex on the concentration of hesperidin was obtained in the interval as $0.60-7.32 \mu \mathrm{g} / \mathrm{mL}$. The regression equation;

$A=-0,0079+0,0186 \cdot c$

was calculated with the aid of Origin v. 7 software, where $A$ is absorbance $(\lambda=283 \mathrm{~nm})$ and $c$ is concentration in $\mu \mathrm{g} / \mathrm{mL}$. The good linearity of the calibration curve and small scatter of experimental points resulted in a high coefficient of determination, $r^{2}=0.9882$.

\section{LOD (Limit of Detection) and LOQ (Limit of Quantification)}

The limit of detection (LOD) was calculated according to the formula: $L O D=3.3 \mathrm{~s}_{b} / \mathrm{a}$, while the limit of quantification (LOQ) was determined by using the formula: $\mathrm{LOQ}=10 \mathrm{~s}_{\mathrm{b}} / \mathrm{a}$. where $\mathrm{s}_{\mathrm{b}}$ is the standard deviation in the intercept and $a$ is the slope of the calibration line [18, 19]. It was found that LOD, establishing the minimum level at which hesperidin can be detected, is $0.15 \mu \mathrm{g} /$ $\mathrm{mL}$, while hesperidin can be quantified at a concentration of $0.45 \mu \mathrm{g} / \mathrm{mL}$.

\section{Precision}

The repeatability of the method was determined for four different hesperidin concentrations (Table 1). The accuracy and repeatability of the method are satisfied, as indicated by good recovery and low values of CV.

\section{The quantitative spectrophotometric determination of hesperidin}

The formation of a stable zinc-hesperidin complex in methanolic solution with enhanced absorbance can be utilized for quantitative determination of hesperidin in both tablets and orange juices in considerable amounts.

We have applied the standard addition method to test the matrix effect of the tested samples. Those preliminary tests showed that nonspecific absorption from juice matrix is eliminated by high dilution of tested juices and there was no need to apply the standard addition method. The same preliminary test (the standard

Table 1. The spectrophotometric determination of hesperidin in aqueous methanolic solutions.

\begin{tabular}{lcccc}
\hline Taken $(\boldsymbol{\mu g} / \mathbf{m L})$ & Found $(\boldsymbol{\mu g} / \mathbf{m L})$ & Recovery (\%) & SD & CV(\%) \\
\hline 0.80 & 0.79 & 98.75 & $9.75 \times 10^{-3}$ & 1.23 \\
2.40 & 2.38 & 99.17 & $1.66 \times 10^{-2}$ & 0.70 \\
5.00 & 5.01 & 100.20 & $1.32 \times 10^{-2}$ & 0.26 \\
\hline
\end{tabular}


addition method) was performed prior to application of the proposed spectrophotometric determination of hesperidin in tested tablets.

\section{Hesperidin content in dietary suplement tablets}

As a result, by the proposed spectrophotometric method, $18.44 \mathrm{mg}$ of declared $20 \mathrm{mg}$ was found in tested suplement tablets, with recovery value of $92.2 \%$ and coefficient of variation $0.70 \%$.

\section{Hesperidin content in orange juices}

Taking into account that citrus and citrus juices are naturally abundant sources of hesperidin, it is necessary to develop a simple, accurate and precise method for its determination in such samples. We found that the method we have proposed has more than satisfactory sensitivity for the routine determination of hesperidin in citrus juices.

The results of hesperidin spectrophotometric determination based on the zinc complex for four commercially available orange juices available on the Serbian market are given in Table $\mathbf{2}$. The recovery values are not given as the tested orange juices do not have declared content of hesperidin.

Table 2. Hesperidin content in tested orange juices.

\begin{tabular}{|l|l|}
\hline Juices & $\begin{array}{l}\text { Hesperidin } \\
\text { content, mg/L }\end{array}$ \\
\hline Sample 1 - pulpy & 67.8 \\
\hline Sample 2 - nectar & 281.9 \\
\hline Sample 3 - 100 \% fruit & 443.9 \\
\hline Sample 4 - 100 \% fruit & 423.2 \\
\hline
\end{tabular}

Without doubt, the reported spectrofluorimetric method [13] leads to better sensitivity and precision of determination, necessary for the quantification in biological fluids. However, having in mind the expected quantity of hesperidin in orange juices, the spectrophotometric method is more than satisfactory.

The linearity range for the spectrophotometric determination of hesperidin reported in literature was from $2.5 \times 10^{-5} \mathrm{~mol} / \mathrm{L}$ to $1.75 \times 10^{-4} \mathrm{~mol} / \mathrm{L}$ [10], while the here developed method may be successfully applied in the range from $1.0 \times 10^{-6} \mathrm{~mol} / \mathrm{L}$ to $1.2 \times 10^{-5} \mathrm{~mol} / \mathrm{L}$. Linearity in such low concentration range provides the use of very diluted samples of juices, which leads to avoiding of matrix effects, as we have confirmed by the standard addition method in our preliminary experiments to verify the method applied to juice samples.

As it was mentioned before, the highest concentration of hesperidin in citrus species fruits are present in the albedo. That is the explanation why citrus juices obtained by squeezing the fruits don't have high concentration of this flavonoid, comparing to industrial produced orange juices, as the most represented citrus juice on the market. These juices are produced by grinding whole fruits, explaining their very high concentration of hesperidin.

According to the Code of Practice for evaluation of quality and authenticity of fruit and vegetable juices, published by the AIJN-European Fruit Juice Association [20], the content of hesperidin is one of the special requirements for quality of citrus based juices such as oranges, lemons and grapefruits, and that has to be 250-700 mg/L.

Results of hesperidin determination of the here proposed spectrophotometric method are within the defined range for all tested juices, except for one, Sample 1. Although the "pulpy" is part of the name of that product, according to very low content of hesperidin, $67.8 \mathrm{mg} / \mathrm{L}$, the fact is that it is not fruit juice, but diluted fruit base with added pulp.

Sample 2 is labeled as nectar, and that is the product containing less than $50 \%$ of fruit content. If we compare the hesperidin content for Sample 2 (281.9 $\mathrm{mg} / \mathrm{L}$ ) with contents for samples 3 and 4 labeled as 100 $\%$ fruit ( 443.9 and $423.2 \mathrm{mg} / \mathrm{L}$ ), it can be observed that two times more fruit content do not result in doubled flavonoid content, such as hesperidin in this particular case. It has been previously reported in literature that sometimes juices labelled as consisting of $50 \%$ fruit nectar content have almost the same quality as those declared as $100 \%$ fruit juice [21]. Although it has been observed a high correlation has been observed between the flavonoids content, the total phenol content, and antioxidant capacities of fruit products such as juices, fruit juice labels based only on fruit \% could sometimes misinform consumers.

It is well known fact that the concentration of bioactive compounds (such as flavonoids) in fruits is a very complex mulitifactorial dependence, related to geographical region, climate, soil type, cultivar methods, growing season, harvest date, storage conditions, low-dose irradiation, and other conditions [22, 23], so like for other compounds, the content of hesperidine could vary in a wide range.

However, here represented results of hesperidin content for all tested samples are in agreement with the Code of Practice for evaluation of quality and authenticity of fruit and vegetable juices, and indicates just the origin, production method and thus the quality of final product are satisfactory.

Although the numerous beneficial effects of daily fruits and vegetables (and therefore flavonoids) intake are a wide spread fact, it should be noted that overlarge intake of hesperidin may trigger a number of side effects, including abdominal pain, diarrhea, and nausea [24]. Because of hesperidin effects, it is necessary to have in mind its possible interactions with certain 
medications such as anticoagulants, blood pressure drugs, and calcium channel blockers. That is one more reason for having more precise data about the content of flavonoids, including hesperidin, and finding the appropriate low-cost method for routine products' analysis, such as juices and dietary supplements.

\section{CONCLUSION}

In this work, a simple spectrophotometric determination of hesperidin in orange juice, after its complexation with zinc(II)-ion, provides good accuracy and precision and may be used for routine analysis for both tablets and orange juices. Tested orange juices fulfill the requirements considered for the content of hesperidin.

\section{ACKNOWLEDGEMENTS}

This work was partly supported by the Ministry for Science and Environmental Protection of the Republic of Serbia, Projects \#172016 and \#172043.

\section{REFERENCES}

1. Prochazkova D, Boušova I, Wilhelmova N. Antioxidant and prooxidant properties of flavonoids. Fitoterapia 2011;82:513-23.

2. Batra P, Sharma AK. Anti-cancer potential of flavonoids: recent trends and future perspectives. Biotech 2013;3(6):439-59.

3. Kay CD, Hooper L, Kroon PA, Rimm EB, Cassidy A. Relative impact of flavonoid composition, dose and structure on vascular function: A systematic review of randomised controlled trials of flavonoid-rich food products. Mol Nutr Food Res 2012;56(11):1605-16.

4. Morand C, Dubray C, Milenkovic D, Lioger D, Martin JF, Scalbert A, et al. Hesperidin contributes to the vascular protective effects of orange juice: a randomized crossover study in healthy volunteers. Am J Clin Nutr 2011;93(1):73-80.

5. Kalpana KB, Devipriya N, Srinivasan M, Vishwanathan P, Thayalan K, Menon VP. Evaluating the radioprotective effect of hesperidin in the liver of Swiss albino mice. Eur J Pharmacol 2011;658(2-3):206-12.

6. Gorinstein S, Huang D, Leontowicz $H$, Leontowicz M, Yamamoto K, Soliva-Fortuny R, Martin Belloso O, Martinez Ayala AL, Trakhtenberg S. Determination of naringin and hesperidin in citrus fruit by high-performance liquid chromatography. The antioxidant Potential of citrus fruit. Acta Chromatogr 2006;17:108-24.

7. Xia J, Kotani A, Hakamata H, Kusu F. Determination of hesperidin in Pericarpium Citri Reticulatae by semi-micro HPLC with electrochemical detection. J Pharm Biomed Anal 2006; 41:1401-5.

8. Volikakis GJ, Efstathiou CE. Determination of rutin and other flavonoids by flow-injection/adsorptive stripping voltammetry using nujol-graphite and diphenylether-graphite paste electrodes. Talanta 2000;51:775-85.

9. Kuntic V, Pejic N, Micic S. Direct spectrophotometric determination of hesperidin in pharmaceutical preparations. Acta Chim Slov 2012;59:436-41.
10. Malešev D, Radović Z, Kuntić V, Kosanić M. Spectrophotometric determination of hesperidin by $\mathrm{Al}(\mathrm{III})$-hesperidin complex in water-methanol solution. Anal Lett 1997;30(5):917-26.

11. Pejić N, Blagojević S, Anić S, Vukojević V, Kolar-Anić Lj. Microquantitative determination of hesperidin by pulse perturbation of the oscillatory reaction system. Anal Bioanal Chem 2005;381:775-80.

12. Tong L, Zhou D, Gao J, Zhu Y, Sun H, Bi K. Simultaneous determination of naringin, hesperidin, neohesperidin, naringenin and hesperetin of Fractus aurantii extract in rat plasma by liquid chromatography tandem mass spectrometry. J Pharm Biomed Anal 2012;58:58-64.

13. Pavun L, Dimitrić Marković J, Đurđević P, Jelikić-Stankov M, Đikanović D, Ćirić A, Malešev D. Development and validation of spectrofluorimetric and LC-MS/MS methods for the determination of hesperidin in human plasma and pharmaceutical forms. J Serb Chem Soc 2012;77(11):1625-40.

14. Pavun L, Jelikić Stankov M, Malešev D, Uskoković-Marković S, Dimitrić Marković J, Đurđević P, Đikanović D. Fluorometric determination of hesperidin in orange juices available on Serbian market. Acta Agriculturae Serbica 2012;XVII(34):93-103.

15. Perrin DD, Dempsey B. Buffers for $\mathrm{pH}$ and Metal Ion Control 1974;77-94. London: Chapman and Hall.

16. Irving H, Pierce T. Observations on Job's method of continuous variations and its extension to two-phase systems. J Chem Soc 1959;2565-74.

17. Yoe J, Jones A. Colorimetric determination of iron with disodium-1,2-dihydroxybenzene -3,5-disulfonate. Ind Eng Chem Anal Ed. 1944;16:111-5.

18. Validation of analytical procedures: Methodology, ICH Guideline Q2B. (1997): Federal Register 62, No 96, pp.27463-27467.

19. Miller JN, Miller JC. Statistics and Chemometrics for Analytical Chemistry, 6th ed. 2010; Harlow, England, Prentice Hall/Pearson.

20. AIJN - European Fruit Juice Association. Available from: http://www.aijn.org/pages/cop/cop.html

21. Pavun L, Uskoković-Marković S, Jelikić-Stankov M, Đikanović $\mathrm{D}$, Đurđević P. Determination of flavonoids and total polyphenol contents in commercial apple juices. Czech J Food Sci 2018;36:233-8.

22. Albach RF, Redman GH, Cruse RR. Annual and seasonal changes in naringin concentration of ruby red grapefruit juice. J Agric Food Chem 1981;29:808-11.

23. Patil BS, Vanamala J, Hallman G. Irradiation and storage influence on bioactive components and quality of early and late season'Rio Red' grapefruit (Citrus paradisi Macf.). Postharvest Biol Technol 2004;34:53-64.

24. Kuntic V, Brborić J, Holclajtner-Antunović I, Uskoković-Marković S. Evaluating the bioactive effects of flavonoid hesperidin - A new literature data survey. Vojnosanit Pregl 2014;71(1):60-5. 


\section{Spektrofotometrijsko određivanje hesperidina u suplementima i sokovima od pomorandže}

\section{Leposava Pavun', Snežana \\ Uskoković-Marković ${ }^{2 *}$}

${ }^{1}$ Katedra za fizičku hemiju i instrumentalne metode, Farmaceutski fakultet, Univerzitet u Beogradu, Vojvode Stepe 450, 11221 Beograd, Srbija

${ }^{2}$ Katedra za analitičku hemiju, Farmaceutski fakultet, Univerzitet u Beogradu, Vojvode Stepe 450, 11221 Beograd, Srbija

\begin{abstract}
Kratak sadržaj
Hesperidin je flavonoidni heterozid koji se najčešce nalazi u citrusnim vrstama, kao što su grejpfrut, limun i pomorandža. Primenjuje se u lečenju brojnih kardiovaskularnih bolesti, sa mnogim proizvodima koji sadrže hesperidin u kombinaciji sa drugim flavonoidnim heterozidima ili vitaminom C. Cilj ove studije je razvijanje i primena jednostavne, brze i osetljive, a pri tome pristupačne metode za određivanje hesperidina u tabletama i sokovima od pomorandže. Razvijena spektrofotometrijska metoda zasniva se na formiranju $\mathrm{Zn}$ (II)-hesperidin kompleksa u $70 \mathrm{v} / \mathrm{v} \%$ metanolu pri $\mathrm{pH} 3,12$, sa maksimumom absorbancije na $\lambda_{\max }=283 \mathrm{~nm}$. Metodom varijacije ekvimolarnih rastvora utvrđena je stehiometrija kompleksa hesperidin: cink = 2:1. Konstanta stabilnosti kompleksa dobijena Bjerumovom metodom iznosi $\log \beta_{2}=17,01$ pri pH 3,12. Linearnost razvijene metode utvrđena je u oblasti $0,61-7,32 \mu \mathrm{g} / \mathrm{mL}$, (potvrđeno koeficijentom određivanja, $r^{2}=0,9882$ ), dok su izračunati limiti detekcije i kvantifikacije $L O D=0,15 \mu \mathrm{g} / \mathrm{mL}$ i $L O Q=0,45$ $\mu \mathrm{g} / \mathrm{mL}$. Na visoku preciznost metode ukazuju niske vrednosti koeficijenata varijacije (CV je u oblasti 0,26-1,23\%). Predložena metoda ispunjava sve postavljene zahteve i sa uspehom je primenjena za određivanje hesperidina u tabletama uz recovery vrednost $92,2 \%$ i komercijalno dostupnim sokovima od pomorandže.
\end{abstract}

Ključne reči: hesperidin, sok od pomorandže, spektrofotometrija, kompleks cinka. 